\title{
Evaluation of the Feeding Potentials of Amaranthus Stem and F. Thoningii Foliage as Supplements to Concentrate Diet for Weaner Rabbits
}

\author{
Yusuf Aliyu* \\ Federal College of Wildlife Management, Nigeria \\ *Corresponding author: Yusuf Aliyu, Federal College of Wildlife Management, PMB 268, New Bussa, Niger State, Nigeria. \\ To Cite This Article: Yusuf Aliyu. Evaluation of the Feeding Potentials of Amaranthus Stem and F. Thoningii Foliage as Supplements to \\ Concentrate Diet for Weaner Rabbits. Am J Biomed Sci \& Res. 2019 - 1(6). AJBSR.MS.ID.000551. DOI: 10.34297/AJBSR.2019.01.000551
}

Received: February 25, 2019 | Published: March 12, 2019

\begin{abstract}
This study was carried out to evaluate the feeding potentials of Amaranthus hybridus stem and Ficus thoningii foliage as supplements to concentrate diet for weaner rabbits over 10 weeks period. A total of 18 crossbred weaner rabbits with average initial weight of $630 \pm 10 \mathrm{~g}$ were used for feeding trial in a completely randomized design experiment. The animals were divided into three groups of six animals per treatment and each treatment had triplicates of two animals per replicate. Treatment T1 was fed with concentrate only. Treatment T2 was fed with concentrate and A. hybridus stem while treatment T3 was fed with concentrate and F. thoningii foliage. Nutrient digestibility of the animals differed significantly $(\mathrm{P}<0.05)$ between the groups. Feed intake and weight gain were higher in T2 than T1 and T3 although feed conversion was better in T1. It is therefore concluded that Amarantus stem can be used as supplement to concentrate diet for weaner rabbits.
\end{abstract}

\section{Introduction}

In recent years interest in rabbit production in Nigeria has increased to improve supply of animal protein from fast growing animals with short gestation period and short generation interval. However, competition between man, animals and industries for conventional feed resources and high cost of compounding concentrate has become a major constraint militating against increased production. The increasing cost of conventional feed ingredients with the resultant increase in the cost of livestock products has necessitated research in the search for cheaper and readily available alternative feed ingredients for livestock feeding. Studies have shown that rabbit can thrive on a number of tropical forages supplemented with concentrate [2,3], but concentrate rations are expensive and can be a constraint to exploitation of the potential of rabbit. Therefore, a feeding strategy that will engage sparing use of concentrate and dependence on forages will be of immense benefit [1]. Such forages must be abundant, available all year round and accessible. Amanranthus hybridus is a widely known leaf vegetable, the foliage of which is utilized and usually discarded as waste. Ficus thoningii is a tree species that is widely distributed in many savanna areas of Nigeria which is also less compete for by man. Utilization of A. hybridus stem and F. thoningii foliage by animals can reduce waste and decrease cost of production. This study was carried out to evaluate the feeding potentials of A. hybridus stem and F. thoningii foliage as supplements to concentrate diet for weaner rabbits.

\section{Materials and Methods}

This research work was conducted at the Teaching and Research Farm of Federal College of Wildlife Management, New Bussa, Niger State, Nigeria. Concentrate diet was compounded as shown in (Table 1). Eighteen crossbred weaner rabbits with average initial weight of $630 \pm 10 \mathrm{~g}$ was used. The animals were divided into three treatment groups of six animals with each group having triplicate of two animals per replicate in a completely randomized design experiment. They were given prophylactic treatment and allowed for two weeks adjustment period followed by 10 weeks experimental period. Treatment 1 (T1) were fed with concentrate diet only while Treatment 2 (T2) were fed with concentrate and A. hybridus stem. Treatment 3 (T3) were fed with concentrate and F. thoningii foliage. Feed and water were served ad-libitum. Feed intake, weight gain and feed conversion ratio were measured. After the feeding trial, seven days digestibility study was conducted. Proximate analyses of the concentrate diet, A. hybridus stem, F. thoningii foliage as well as faecal samples were carried out according to [4]. All data collected 
were subjected to statistical analysis using statistical package for social science [5] significant means were separated using Duncans Multiple Range test of the same package.

\begin{tabular}{|c|c|}
\hline Table 1: Composition of the experimental diets. \\
\hline Ingredient & Percentage (\%) \\
\hline Maize bran & 64.61 \\
\hline Groundnut cake & 18.39 \\
\hline Blood meal & 3 \\
\hline Rice husk & 10 \\
\hline Bone meal & 3 \\
\hline Salt & 0.5 \\
\hline Premix & 0.5 \\
\hline Total & 100 \\
\hline Calculated composition & 18 \\
\hline Crude protein (\%) & 11.7 \\
\hline Crude fiber (\%) & 2580 \\
\hline Metabolizable Energy (Kcal/Kg & \\
\hline
\end{tabular}

\section{Results and Discussion}

The results of proximate analyses of the concentrate, A. hybridus stem and F. thoningii is presented in (Table 2). Nutrient digestibility is shown in (Table 3). Dry matter (DM), crude protein (CP), ether extract (EE), Ash and Nitrogen free extract (NFE) were more digestible in animals on concentrate only than animals on concentrate and forages but crude fibre was more digestible in animals on concentrate and forages than those on concentrate only. Similarly, with the exception of ether extract, all other nutrients were more digestible in animals on A. hybridus than those on F. thoningii. This is an indication that A. hybridus stem is more digestible than F. thoningii. The reason may probably be due to some anti-nutritional factors present in F. thoningii. This is in time with the report of [6] who stated that a variety of anti-nutritional factors can affect digestion, reduce growth and affect body metabolism of animals. Digestibility of nutrients differ significantly $(\mathrm{P}<0.05)$ between the treatment groups. Results of feed intake, weight gains and feed conversion ratio are presented in (Table 4). Average daily feed intake (ADFI) of animals on concentrate diet only (T1) was $43.00 \mathrm{~g}$ with corresponding average weight gain (AWG) of 14.00 g. ADFI of animals fed concentrate and A. hybridus stem (T2) was $80.50 \mathrm{~g}$ with concentrate and A. hybridus consumption of $30.20 \mathrm{~g}$ and 50.30 g respectively to gain $17.14 \mathrm{~g}$. Similarly, ADFI of animals fed concentrate and F. thoningii (T3) was $65.50 \mathrm{~g}$ with concentrate and F. thoningii consumption of $30.00 \mathrm{~g}$ and $35.50 \mathrm{~g}$ respectively to gain $12.86 \mathrm{~g}$. ADFI and AWG were better in animals on concentrate and $A$. hybridus stem than other groups. Feed conversion ratio was lower in $\mathrm{T} 1$ than $\mathrm{T} 2$ and $\mathrm{T} 3$. All the values obtained for all the parameters were significantly $(\mathrm{P}<0.05)$ different between the treatments. Although higher feed intake with corresponding higher gain were recorded in $\mathrm{T} 2$, feed was better converted to carcass in T3. However, T2 had higher gain and better conversion than T3. This could be due to higher CP, lower CF and succulent nature of A. hybridus stem compared to $\mathrm{F}$. thoningii foliage. The observation is in line with the report of [1]. Higher CF in F. thoningii than in A. hybriduss stem may also be a factor that led to lower feed intake and lower digestibility in $\mathrm{T} 3$ than in $\mathrm{T} 2$. This observation is in line with report of [7] who reported reduced digestibility due to high levels of dietary fibre. This apart, the significantly lowest feed intake and weight gain of rabbits on T3 possibly suggests that $\mathrm{F}$. thoningii may likely contain some anti-nutritional factors which must have affected its intake and utilization. The results of this study had indicated that rabbit can perform well when fed with concentrate diet supplemented with A. hybridus stem. This agrees with the conclusion of [8] who concluded that rabbits can perform well with mixed regime of forages and concentrate.

Table 2: Proximate Composition of the experimental concentrate, A. hybridus stem and Ficus thoningii foliage.

\begin{tabular}{|c|c|c|c|}
\hline Nutrient (\%) & Concentrate & $\begin{array}{c}\text { A. hybridus } \\
\text { stem }\end{array}$ & F. thoningii \\
\hline Dry matter & 91.7 & 50.48 & 64.32 \\
\hline Crude protein & 17.89 & 10.05 & 9.73 \\
\hline Crude fibre & 12.2 & 15.31 & 18.56 \\
\hline Ether extract & 6.52 & 3.2 & 5.92 \\
\hline Ash & 8.34 & 4.68 & 7.32 \\
\hline $\begin{array}{c}\text { Nitrogen free } \\
\text { extract }\end{array}$ & 55.05 & 66.76 & 58.47 \\
\hline
\end{tabular}

Table 3: Nutrient Digestibility of the experimental rabbits.

\begin{tabular}{|c|c|c|c|c|}
\hline Nutrient (\%) & T1 & T2 & T3 & SEM \\
\hline Dry matter & $68.42 \mathrm{a}$ & $64.37 \mathrm{a}$ & $62.05 \mathrm{~b}$ & 3.06 \\
\hline Crude protein & $70.38 \mathrm{~b}$ & $66.48 \mathrm{~b}$ & $60.85 \mathrm{c}$ & 2.82 \\
\hline Crude fibre & 58.1 & 60.29 & 59.92 & 1.01 \\
\hline Ether extract & $63.39 \mathrm{a}$ & $59.30 \mathrm{~b}$ & $60.05 \mathrm{~b}$ & 1.14 \\
\hline Ash & $59.75 \mathrm{a}$ & $56.62 \mathrm{~b}$ & $53.26 \mathrm{c}$ & 1.26 \\
\hline $\begin{array}{c}\text { Nitrogen free } \\
\text { extract }\end{array}$ & 62.38 & 57.97 & $52.08 \mathrm{c}$ & 2.86 \\
\hline
\end{tabular}

$a, b, c, d$ Means in the same row with different superscripts differ significantly $(P<0.05)$

SEM $=$ Standard Error of Mean

Table 4: Performance characteristics of the experimental rabbits.

\begin{tabular}{|c|c|c|c|}
\hline Parameters & T1 & T2 & T3 \\
\hline Initial weight (g) & 630 & 620 & 640 \\
\hline Final weight (g) & $1,610.00 \mathrm{~b}$ & $1,819.80 \mathrm{a}$ & $1540.20 \mathrm{c}$ \\
\hline Total weight gain (g) & $980.00 \mathrm{~b}$ & $1,199.80 \mathrm{a}$ & $900.20 \mathrm{c}$ \\
\hline $\begin{array}{l}\text { Average weight gain } \\
\text { (g) }\end{array}$ & $14.00 \mathrm{~b}$ & $17.14 \mathrm{a}$ & $12.86 \mathrm{~b}$ \\
\hline $\begin{array}{l}\text { Total feed intake/ } \\
\text { day (g) }\end{array}$ & $43.00 \mathrm{c}$ & $80.50 \mathrm{a}$ & $65.50 \mathrm{~b}$ \\
\hline $\begin{array}{l}\text { Average forage } \\
\text { intake/day (g) }\end{array}$ & - & $50.30 \mathrm{a}$ & $35.50 \mathrm{~b}$ \\
\hline $\begin{array}{l}\text { Average Concentrate } \\
\text { intake/day (g) }\end{array}$ & $43.00 \mathrm{a}$ & $30.20 \mathrm{~b}$ & $30.00 \mathrm{~b}$ \\
\hline Feed conversion ratio & $3.07 \mathrm{c}$ & $4.70 \mathrm{~b}$ & $5.09 \mathrm{a}$ \\
\hline \multicolumn{4}{|c|}{$\begin{array}{l}\text { a. b. c. d Means in the same row with different superscripts differ } \\
\text { significantly }(\mathrm{P}<0.05)\end{array}$} \\
\hline
\end{tabular}




\section{Conclusion}

In conclusion, the results of this study had indicated that A. hybridus stem have potentials to support growth when fed with concentrate diet to weaner rabbits. It is therefore recommended that A. hybridus stem be used in mixed feeding regime for weaner rabbits especially during dry season when forages are scarce.

\section{References}

1. Yusuf AM, Olafadehan OA, Garba MH (2010) Evaluation of the feeding potentials of Vitellaria paradoxa, Nauclea latifolia and Terminalia macroptera foliage as supplements to concentrate feed for grower rabbits. Australian Journal of Basic and Appplied Science 4(3): 429-433.

2. Odeyinka SM, Ijiyemi OC (1997) Performance of rabbits fed Leucaena leucocephala and concentrate between $9^{\text {th }}$ and $25^{\text {th }}$ weeks of age. Nigerian Journal of Animal Production 24(1): 51-53.

3. Shiawoya EL, Musa JAO (2003) Evaluation of the feeding potentials of mango (Mangifera indica) leaves, banana (Musaspp) leaves and Tridax (Tridax procumbens) as supplements to conventional feeds for growing rabbits. Proceeding of $8^{\text {th }}$ Annual Conference of Animal Science Association of Nigeria (ASAN). pp 90-92.
4. AOAC (1990) Official Methods of Analysis. Association of Official Analytical Chemists, $\left(15^{\text {th }}\right.$ edn), Washington, D.C, USA.

5. Statistical Package for Social Science (1980) SPSS for windows version 11.

6. Maidala AA, Doma UD, Aighigh DT (2011) Growth performance of weaner rabbits fed diets containing differently processed soyabean (Glycine max L. merril) products. Proceedings of $36^{\text {th }}$ Annual conference of Nigerian Society for Animal Production (NSAP), Nigeria. pp 315-317.

7. Ezenwa, L., Bamikole, M.A. and Akinsoyinnu A.O. (1998). The feeding value of Verano stylo and Guinea grass hays as dry season feeds for rabbits. Proceedings of the $3^{\text {rd }}$ Annual Conference of Animal Science Association of Nigeria (ASAN). September 22-24, Ikeja, Lagos, Nigeria. pp 203-205.

8. Bamgbose AM, Akinnusi FAO, Kuforiji AT, Osofowora AO, Osa AO, et al. (Ä3) Growth reponse of weaner rabbits fed concentrate/forage supplemented based diets. Proceedings of $8^{\text {th }}$ Annual Conference of Animal Science Association of Nigeria (ASAN). September 15-18. Federal University of Technology, Minna, Nigeria. pp 98-99. 